\title{
14 \\ TAX INCENTIVES FOR CHARITABLE GIVING
}

\section{Evidence from the Swiss Canton of Geneva}

\author{
Giedre Lideikyte Huber, Marta Pittavino and Henry Peter
}

\section{Introduction}

\section{a Current Swiss legal framework}

Switzerland is one of the countries whose legal framework includes a system of tax deductions to incentivize charitable giving (OECD 2020). ${ }^{1}$

Under the current Swiss law, taxpayers can deduct charitable donations from their taxable income (individuals) or taxable profits (corporations) subject to a specific threshold. In order to be deductible, the donation must be made to legal entities that benefit from a tax exemption as a result of the fact that they are pursuing public service or public-interest goals. ${ }^{2}$ The law and case law specify the tax-exemption conditions for such entities, notably that economic goals cannot be considered public-interest purposes and that acquiring and managing significant corporate equity is considered a public-interest goal only when the interest in keeping such an entity is subordinate to the public-interest goals [Art. 56 (g) LIFD]. Such exoneration requirements apply to the entities subjected to limited and unlimited tax liability in Switzerland, that is, both to resident entities and to permanent establishments. Legal entities governed by public law and semi-public companies do not fall into this scope. ${ }^{3}$

A threshold applies to the amount of the deduction of charitable donations from taxable income and profits. At the federal level, this threshold is $20 \%$ of the net taxable income or profits with a minimum donation requirement of CHF 100. Nearly all cantonal legislations adopted the same limit of $20 \%$ (often without minimum donation requirement), even though federal law does not impose any requirement in this respect: ${ }^{4}$ as a result of the principle of the cantonal autonomy in fixing tax rates, which is enshrined in the Art. 129 of the Swiss Federal Constitution, tax allowances applied by the cantons and the communes are in effect their sole prerogative. The threshold of a charitable deduction is calculated as follows: first, one must discount all deductions from the gross income that are mentioned in articles 26 to 33 of the DFTA (those include the deductions related to self-employed business activity, to wealth, social deductions, etc.). Second, the calculation of the $20 \%$ threshold is based on the remaining taxable income after these deductions. The charitable donation is deducted from the remaining income and capped - if necessary - at the aforesaid threshold.

* The authors greatly thank the Geneva Tax Administration for providing data for this study. 


\section{$b$ The 2006 federal direct tax law reform}

The 20\% threshold of taxable income or profits was introduced on January 1, 2006, as part of a larger reform of the Swiss federal tax law. ${ }^{5}$ Prior to this reform, the threshold was $10 \%$. The goal of the 2006 reform was "the liberalization of the Swiss foundation law in order to boost the establishment of foundations". ${ }^{6}$ Through this reform, the legislator in fact expressed its will to encourage more people "to give up part of their wealth" to charitable foundations, due to the fact that private foundations were the most popular vehicles (though not the only ones) in Switzerland for hosting charitable activities, as well as the fact that private wealth had risen sharply in the years preceding the reform. ${ }^{7}$ The main part of this reform aimed at modifying civil law norms related to different aspects of foundations. However, tax law modifications were also carried out as the previous legal framework was considered an insufficient incentive for individuals to part with "important" portion of their wealth. ${ }^{8}$ Thus, even though the objectives of these changes were only articulated in very general terms ${ }^{9}$ (which in itself is problematic), it is safe to assume that at least one of its goals was to encourage significant donations.

The federal tax law amendments directly impacted charitable giving in three manners. ${ }^{10}$ First, as already said, the existing threshold for deduction of charitable donations was increased from $10 \%$ to $20 \%$ of taxable income or profits. Second, the law introduced a possibility to deduct non-cash donations. Third, the law added a new clause stating that donations to the Swiss Confederation, the cantons, the communes and their institutions are deductible to the same extent as donations to charitable tax-exempt entities. Overall, those three tax law amendments significantly expanded the potential for tax deductions.

During the legislative process, the most important discussions concerned the first measure, that is, the increase in the threshold for deductible donations. The Economic Affairs and Taxation Committee of the Council of States, ${ }^{11}$ reporting on this legislative proposal, was convinced that the activities of foundations pursuing public service or public utility goals would effectively be fostered through a more generous practice of deducting donations, as proposed by the reform. ${ }^{12}$ In fact, the initial project suggested increasing the deductions for direct federal tax to $40 \%$ of net income or net profit. What is more, under certain specific conditions, such as a particularly important public interest, an enduring commitment to finance a foundation and at least an equivalent deduction granted by a canton and municipality (the latter norm had some logic of "matching" mechanisms), the tax deduction allowed by the direct federal tax would have been able to reach even $100 \%{ }^{13}$ Thus, the initial suggested changes offered very generous tax deductions.

However, the large increases in deductible thresholds were dismissed in the context of the legislative procedure. During the consultation phase with the cantons, which is a part of the legislative process in Switzerland, ${ }^{14}$ the vast majority of cantons resolutely rejected a quadrupling of the deduction (from $10 \%$ to $40 \%$ ). ${ }^{15}$ As a result, the $100 \%$ deduction, even in restrictive conditions, was also rejected, on the basis that it would affect the fiscal substance of the public authorities too profoundly. ${ }^{16}$ The Federal Council used public law and finance arguments to reject the proposed increases. It highlighted that this type of deduction leads to unequal treatment, as taxpayers taxed at high marginal tax rates are favored over those with lower incomes. Also, extending too widely the possibility of making a deduction seriously undermines the distinctive fiscal character of taxes, whose goal is to finance the tasks of the State, whatever they may be. ${ }^{17}$ In addition, the Federal Council pointed out that the norms instituting such deductions were questionable from a public finance perspective, because not only they do not respect 
the principle of "gross accounting", but they also ultimately restrict the financial sovereignty of the Federal Parliament. In particular, by allowing a taxpayer to decide on the allocation of certain funds to certain public tasks, the system would be delegating some budgetary authority to the taxpayer; such standards are not compatible with the requirements of the Federal Finance Act. ${ }^{18}$ In the end, the threshold of $20 \%$ was adopted. ${ }^{19}$

Other tax law changes did not give rise to controversial discussions. The deductibility of non-cash donations was widely approved, with some cantons only pointing out the potential valuation problems that could arise. ${ }^{20}$ The deductibility of voluntary contributions to the Confederation, the cantons, the communes and their related public institutions was also introduced without particular objections. In fact, the reason behind this provision was mainly to ensure that universities, which in Switzerland are mainly federal or cantonal institutions, ${ }^{21}$ also benefit from the liberalization of the charitable deductions system: the proposal highlighted the need to fund considerable investments in teaching, research and science. ${ }^{22}$ The Economic Affairs and Taxation Committee specifically highlighted in its Report that donations for research and education were very relevant for the State and could help to relieve its burden in this area. ${ }^{23}$

The federal law changes were followed by cantonal law modifications. In Geneva, the threshold of $5 \%$ of the taxable net income ${ }^{24}$ was raised to $20 \%$ in $2010 .{ }^{25}$ In 2009 , deductions for legal entities were raised from $10 \%$ of the taxable corporate income to $20 \%{ }^{26}$

The introduction of different thresholds in the Swiss federal and Geneva cantonal law was introduced as shown in Table 14.1.

\section{c Objectives}

To our knowledge, the effectiveness of the 2006 income tax law reform has never been evaluated, neither at the federal nor at cantonal level. ${ }^{27}$ In general, very little research and data exist in Switzerland regarding taxpayers' giving behavior in relation to tax incentives. Therefore, the aim of this chapter (which is a part of a larger project evaluating the efficiency of tax incentives for charitable giving in Switzerland) is to provide, using descriptive statistics, a first insight into the charitable giving behavior in the Canton of Geneva (GE) and to identify any possible changes in behavior - if any - correlated with the 2006 tax reform. The Canton of Geneva is one of the most important cantons in Switzerland, having the fifth-largest population and secondhighest gross domestic product per capita. ${ }^{28}$ Also, and importantly, it is a national as well as international philanthropy hub. As a result, observing the patterns of charitable giving behavior in relation to tax incentives among the Geneva population may provide significant information for policymakers.

Table 14.1 Deductible thresholds in federal and Geneva cantonal income tax laws during the studied timeframe

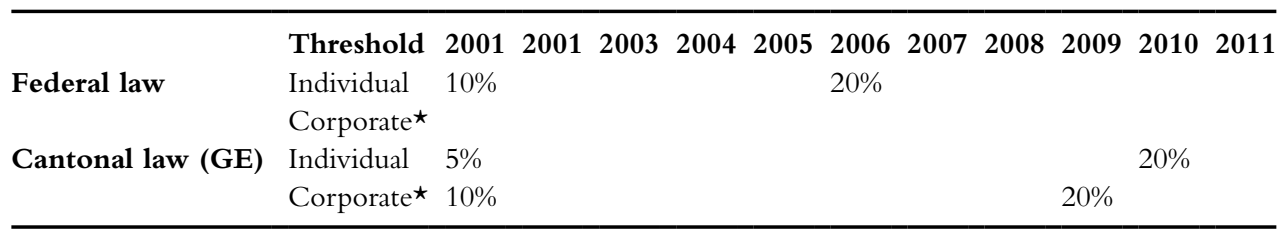

* This table shows both individual and corporate income tax thresholds; however, the focus of the current chapter is only on individual income taxation. 
The present chapter focuses on the tax filing data described in the following section. It analyses the giving behavior which can be observed on the basis of tax returns and not the overall charitable giving behavior (e.g. donations not claiming any tax deductions for their gifts) (see Adena, Chapter 12; Adena et al. 2014; Adena and Huck 2019). ${ }^{29,30,31}$ This chapter will therefore not provide conclusions about the general giving behavior in the Canton of Geneva; it only focuses on specific tax-related patterns. In addition, based on this study, it will not be possible to draw definitive conclusions as to whether the changes of giving behavior - if any - were caused by a specific measure of the previously mentioned reform (increase in threshold, introduction of the possibility of non-cash deductions or the possibility to deduct donations to State entities), as segregated data for those categories were not available.

\section{Material and methods}

The outcomes presented in this chapter are related to taxpayer behavior for charitable giving over a time framework of 11 years (2001-2011) based on data from the Canton of Geneva.

Data were collected in the given years by the Tax Administration of the Canton of Geneva through its taxpayers' returns and were confidentially shared for the sake of our analysis. A different data set was provided for each year under study for a total of 11 data sets. Each data set consisted of the same eight variables, listed and described in the following with the original French name provided in the data set:

- "identifiant": a coded ID for each taxpayers. This variable allows, in principle, to follow the same taxpayer over time. In other words, the same coded ID is used for a given taxpayer for each fiscal year. As Switzerland has a joint filling system, married couples are considered and treated as one taxpayer in the same way as a single non-married individual and have only one coded ID (in this chapter, any deducting taxpayer, couple or individual is referred to as "deducter"). The code ID may change from one year to another in specific cases, mainly therefore: 1) replacement of one ID by another in the event of the death of a married taxpayer ("principal" taxpayer) by his surviving spouse; 2) disappearance of an ID in case of marriage between two taxpayers: the "main" taxpayer (often the husband) remains, and the spouse disappears; 3) appearance of a new ID in the case of divorce or separation of two taxpayers: the "main" taxpayer (often the husband) remains, and the spouse appears; 4) replacement of one ID by another in case of a change of surname or modification/correction of the date of birth. In all four situations, it is not possible to track a given taxpayer over time.

- "annee_de_naissance": the year of birth of a taxpayer. For married couples, it is the year of birth of the "principal" taxpayer.

- “revenu_net_imposable_GE": the net taxable income in the Canton of Geneva. In 2010 and 2011, the canton of Geneva has introduced several changes to its personal income tax law (e.g., extension of the deduction for family expenses). Those changes to a certain extent influenced the definition of taxable income for cantonal tax purposes. For this reason, the calculation of taxable income of 2001 through 2009 to a certain extent diverges from its calculation in 2010 and 2011..$^{30}$

- "revenu_net_imposable_taux": the net taxable income applied to set the tax rate; it includes any foreign income.

- "fortune_brute": gross wealth.

- "fortune_imposable": taxable wealth. 
- "bareme_revenu": the binary (0/1) indication of a possible "splitting" of income tax rate in the tax income computation, showing if a taxpayer is a couple (1) and not a single individual (0) (see the previous description of "identifiant").

- "versements_benevoles": the amount of deduction (if any) for charitable giving, representing the entire annual amount of the deducted donations (in case it is less than the deductible threshold) or capped amount of annual donations, if exceeding the deductible threshold.

Since the main relevant variables for the purpose of this study were "identifiant" and "versements_benevoles", a longitudinal data set representing the Canton of Geneva taxpayers from 2001 to 2011 was created and analyzed. In addition, we have used the variable net taxable income for tax rate overall ("revenu_net_imposable_taux") to identify patterns of giving behavior in 2001 and 2011. The outcomes are summarized in the "Results" section.

The characteristics of the available data do not allow checking whether the amounts deducted by taxpayers represent the full donation or only the part capped at the threshold level (10\% prior to 2006 and $20 \%$ after 2006 for federal income tax purposes); as a result, in certain cases (which we cannot identify), only the deducted amount and not the whole amount of donation can be observed. In other words, the total amounts of all charitable donations are not known to us for the given 11 years (2001-2011) in the Canton of Geneva, as the present data encompass both the un-capped deductions (representing full amounts of donations) and the capped deductions (representing incomplete amounts of donations) without distinguishing between those two categories. ${ }^{31}$

\section{Results}

The total number of Geneva taxpayers was calculated. Its trend positively increased every year, from a minimum of 234,117 in 2001 to a maximum of 266,336 in 2011. The percentage change over the years is reported in the last column of Table 14.2, together with the percentage of Geneva deducting taxpayers (second-to-last column) computed for each of the 11 years in the given time framework period. From 2001 to 2011, the number of deducting taxpayers more than doubled, going from $8.3 \%$ of the total number of taxpayers in 2001 to $19.3 \%$ of the

Table 14.2 Descriptive statistics of taxpayers' population by year (2001-2011)

\begin{tabular}{llllcl}
\hline Year & $\begin{array}{l}\text { Number of } \\
\text { taxpayers }\end{array}$ & Deducting & $\begin{array}{l}\text { Non- } \\
\text { deducting }\end{array}$ & $\begin{array}{l}\text { \% of deducting } \\
\text { taxpayers }\end{array}$ & $\begin{array}{c}\text { \% yearly change } \\
\text { in taxpayers }\end{array}$ \\
\hline 2001 & 234,117 & 19,335 & 214,782 & $8.3 \%$ & $0.9 \%$ \\
2002 & 236,341 & 25,272 & 211,069 & $10.7 \%$ & $0.6 \%$ \\
2003 & 237,777 & 30,276 & 207,501 & $12.7 \%$ & $1.0 \%$ \\
2004 & 240,254 & 35,192 & 205,062 & $14.7 \%$ & $0.9 \%$ \\
2005 & 242,521 & 39,553 & 202,968 & $16.3 \%$ & $1.1 \%$ \\
2006 & 245,224 & 39,511 & 205,713 & $16.1 \%$ & $1.1 \%$ \\
2007 & 248,017 & 42,248 & 205,769 & $17.0 \%$ & $1.2 \%$ \\
2008 & 250,886 & 44,707 & 206,179 & $18.0 \%$ & $2.1 \%$ \\
2009 & 256,236 & 47,349 & 208,887 & $18.5 \%$ & $2.1 \%$ \\
2010 & 261,703 & 49,389 & 212,314 & $18.9 \%$ & $1.8 \%$ \\
2011 & 266,336 & 51,492 & 214,844 & $19.3 \%$ & \\
\hline
\end{tabular}


total number of taxpayers in 2011. The absolute numbers of these values are 19,335 (number of deducting taxpayers in 2001) and 51,492 (number of deducting taxpayers in 2011). Further, detailed information for the years under review can be found in Table 14.2, including the absolute number of non-deducting taxpayers and the percentage change of taxpayers from one year to the other.

Table 14.2 shows the absolute number of taxpayers, split between deducting and not deducting, from year 2001 to year 2011. The percentage of Geneva deducting taxpayers, and related changes, are also shown.

The total amount of deductions has been computed from year 2001 to year 2011. The amounts presented in the current chapter were not inflation-adjusted; however, the income classes were objectively computed by population percentages $(25 \%, 25 \%, 25 \%, 20 \%, 4 \%, 1 \%)$. The absolute range for the amount of deductions is large, going from a minimum of CHF 29,133,697 in 2001 to a maximum of CHF 84,014,116 in 2010, with a substantial increase of $48 \%$ from 2008 to 2009 . Overall, the total amount of deductions positively increased between 2001 and 2010, with a negligible (-0.7\%) decrease from 2005 to 2006 and a slightly higher decrease (-13.4\%) from 2010 to 2011, as shown in the third column of Table 14.3. While the mean deductions range varies from a minimum of CHF 1,098 to a maximum of CHF 1,701, with a CHF 603 difference and a mainly negative trend between the years, the median deduction range is smaller: from 270 to 393, with a difference of CHF 123 and a slow decrease over the years as seen in Figure 14.2. The latter result is validated by the outcome presented in the last column of Table 14.3, showing a prevalence of negative percentage of the change in median deductions among deducters from 2001 to 2011.

Table 14.3 represents the amount of deductions and related percentage change from 2001 to 2011. The mean and median deductions among deducters, together with the latter percentage change, are also reported.

In addition, we have carried out an analysis of giving by income using as a variable the taxable income for tax rate ("revenu_net_imposable_taux"). To that effect, we have divided the taxpayers by income classes into six categories, representing the following percentages of the taxpayer population (see Annexes 1 and 2): "low" (bottom 25\% of taxpayers), "low-middle" ( $25 \%$ of taxpayers) and "middle" (25\% of taxpayers). The remaining $25 \%$ of the taxpayers have

Table 14.3 Amount of deductions and related percentage change from 2001 to 2011

\begin{tabular}{llllll}
\hline Year & $\begin{array}{l}\text { Amount of } \\
\text { deductions } \\
\text { (CHF) }\end{array}$ & $\begin{array}{l}\text { \% yearly change } \\
\text { in the amount of } \\
\text { deductions }\end{array}$ & $\begin{array}{l}\text { Mean deductions } \\
\text { among deducters } \\
\text { (CHF) }\end{array}$ & $\begin{array}{l}\text { Median deductions } \\
\text { among deducters } \\
\text { (CHF) }\end{array}$ & $\begin{array}{l}\text { \% change in } \\
\text { median deductions } \\
\text { among deducters }\end{array}$ \\
\hline 2001 & $29,133,697$ & & 1,507 & 393 & $-8.4 \%$ \\
2002 & $33,248,984$ & $14.1 \%$ & 1,315 & 360 & $-15.3 \%$ \\
2003 & $33,507,115$ & $0.8 \%$ & 1,098 & 305 & $-1.6 \%$ \\
2004 & $41,229,743$ & $23.0 \%$ & 1,171 & 300 & $0.0 \%$ \\
2005 & $47,381,886$ & $14.9 \%$ & 1,197 & 300 & $-0.7 \%$ \\
2006 & $47,056,580$ & $-0.7 \%$ & 1,190 & 298 & $-6.0 \%$ \\
2007 & $50,968,564$ & $8.3 \%$ & 1,206 & 280 & $-3.6 \%$ \\
2008 & $51,735,693$ & $1.5 \%$ & 1,147 & 270 & $3.7 \%$ \\
2009 & $76,574,313$ & $48.0 \%$ & 1,617 & 280 & $3.6 \%$ \\
2010 & $84,014,116$ & $9.7 \%$ & 1,701 & 290 & $-3.4 \%$ \\
2011 & $72,741,235$ & $-13.4 \%$ & 1,412 & 280 & \\
\hline
\end{tabular}


been divided into smaller income categories in order to make an in-depth analysis of the giving behavior of taxpayers belonging to the highest income classes. Thus, the following income class categories were established: "middle-high" ( $20 \%$ of taxpayers), "high" (4\% of taxpayers) and "very high" (top $1 \%$ of taxpayers).

The analysis by income class shows that the amount of charitable deductions increases with the increase of the taxpayers' income. The largest amount of deductions is provided by the taxpayers belonging to the highest income class ("very high", i.e., $1 \%$ ), accounting for $23.1 \%$ (2001) and 37.8\% (2011) of deducting taxpayers as in Figure 14.1. The top 25\% income classes (middle-high, high and very high together) account for 79.6\% (2001) and 73.8\% (2011) of the total deductions. The percentage of taxpayers deducting charitable donations in the respective income classes also increases along with income. Also, in every income class, we observe
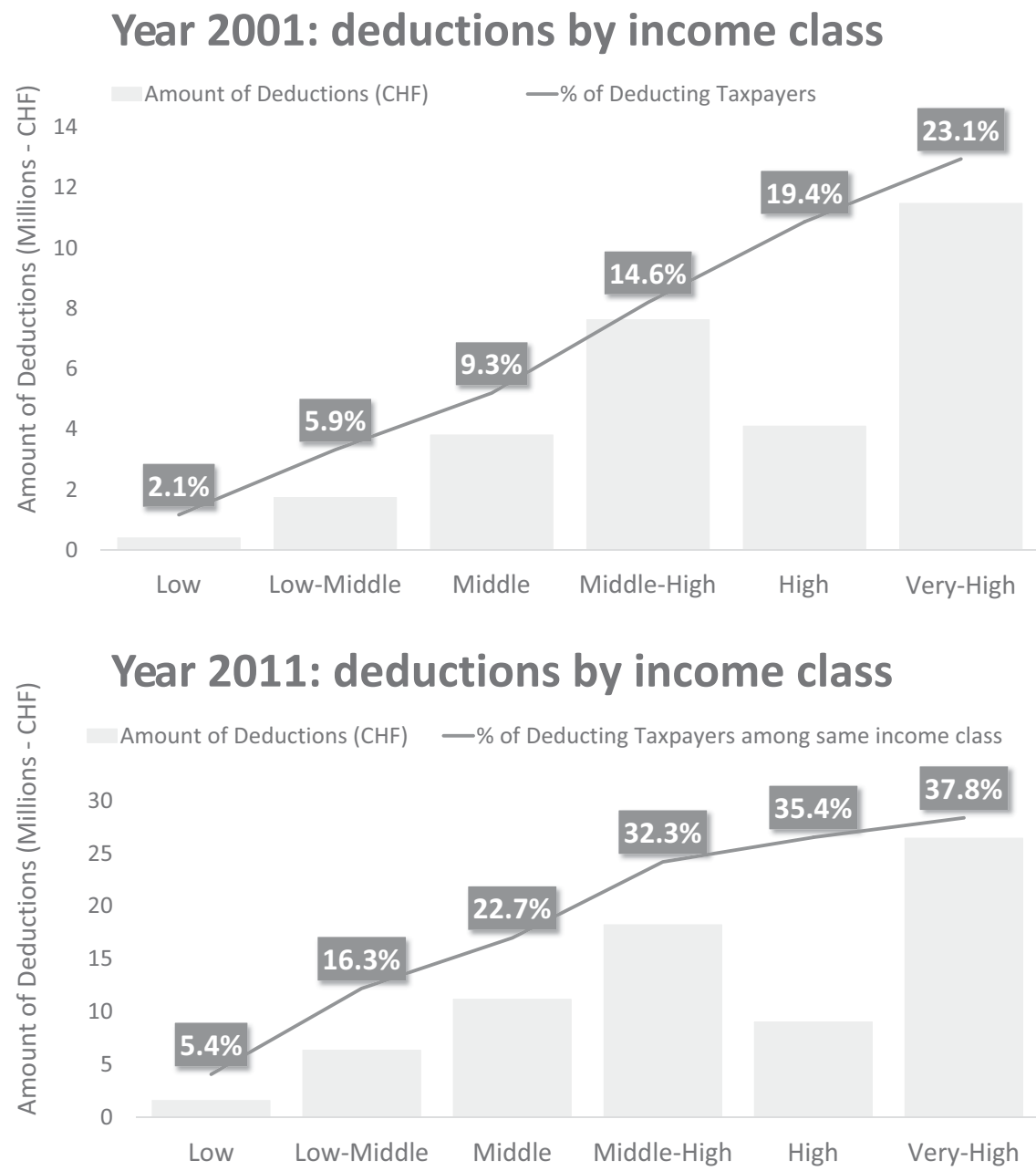

Figure 14.1 Amount of deductions and percentage of deducting taxpayers for each of the six income class categories in the year 2001 (above) and in the year 2011 (below). The six income class categories represent different percentages of the total income amount: Low, Low-Middle and Middle correspond to 25\% each, while Middle-High indicates 20\%, High 4\% and VeryHigh the top $1 \%$ 


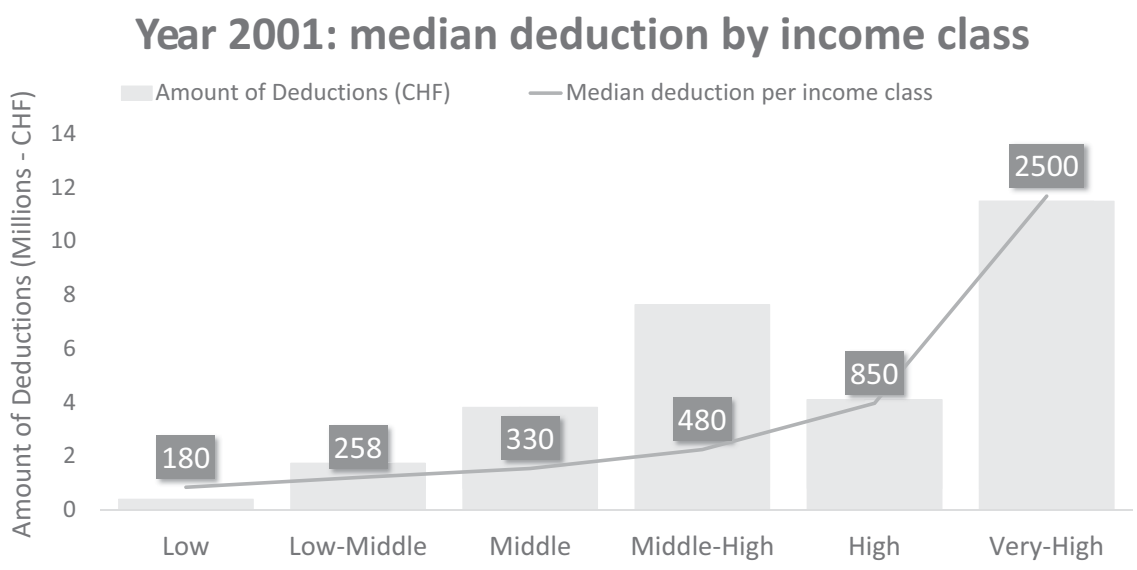

\section{Year 2011: median deduction by income class}

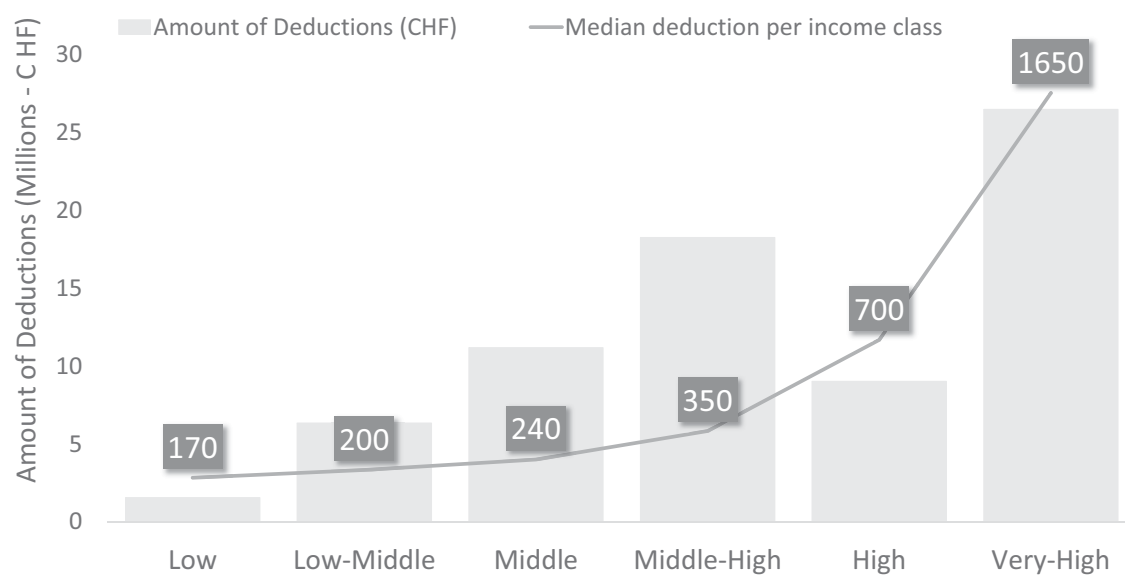

Figure 14.2 Amount of deductions and median deductions for each of the six income class categories in the year 2001 (above) 2011 (below). The six income class categories represent different percentages of the total income amount: Low, Low-Middle and Middle correspond to 25\% each, while Middle-High indicates 20\%, High 4\% and Very-High the top 1\%

an important increase in deducters in 2011 in comparison with 2001. Concerning the median deductions by income class, they also increase with the increase of income, rising especially sharply in the last three income classes. However, the median deductions in all income classes are significantly lower in 2011 than in 2001 as shown in Figure 14.2.

\section{Discussion}

The descriptive statistics presented in the "Results" section of this study provide several insights into taxpayer's giving behavior in the Canton of Geneva; these could be of interest for policy makers. In addition, it offers a first glimpse into the effects - if any - of the 2006 tax reform.

The first observation is that the percentage of deducters among Geneva's taxpayers more than doubled, from $8.3 \%$ to $19.3 \%$, during the studied period from 2001 to 2011). In 2011, nearly 
one fifth of the Geneva population made charitable gifts for which they claimed charitable deductions, as opposed to less than one tenth of the taxpayers in 2001. Unambiguously, the use of these specific deductions has risen among taxpayers, and we observe this increase in every income class (Annex 1). Even though we can only speculate about the reasons for this increase (i.e., better awareness about the possibility to deduct gifts? An increase in the number of donors in the Canton of Geneva? An effect of the higher incentive? Other?), these data show that the relevant period claiming charitable deductions has become a common and not a marginal phenomenon during the process of filling tax returns.

This finding raises interesting questions when compared to other available data sources on giving behavior. For instance, the study of Freitag et al. reports that in 2014, 71\% of the Swiss population made charitable donations. However, our data show that, at least in the Canton of Geneva, only 19\% of taxpayers filed for charitable deductions in 2011. This number reflects tax fillings that occurred three years earlier than the study of Freitag et al., but judging from the level of increase in charitable deductions in Geneva during the 11-year period under review, it is quite unlikely that charitable deductions reached $71 \%$ in 2014 . Therefore, further studies should look into the differences in various data sets describing individual charitable giving behavior in Switzerland. For instance, it would be interesting to assess whether and to what extent the estimated percentage (71\%) of charitable giving by the Swiss population is accurate and, if it is, why an important portion of Swiss taxpayers still does not seem to deduct charitable donations.

In terms of the amount of deductions in relation to charitable donations, the total annual sum deducted by all taxpayers is steadily increasing during the observed period. It is in fact possible to observe a correlation with 1) the increase in the overall population of taxpayers and 2) the increase of charitable deductions among taxpayers. In terms of deductions per taxpayer, we observe a decrease both in the mean and in the median over time. While the median constantly decreases, the mean of donations fluctuates during the studied period but is overall lower in 2011 than in 2001. We observe the same trend when comparing median charitable deductions by income classes. In other words, the general trend seems to be lesser deductions, and this may be a clue showing that, considered individually, taxpayers tend to give less, that is, that the size of the individual donations is decreasing. However, a complementary set of data showing the exact amount of donations (and not only the deducted amounts) would be needed to verify such a hypothesis.

The data presented in the present chapter offers rare glimpse of the Swiss taxpayers' giving behavior per income class. In particular, having compared 2001 to 2011, we observe that the deductions made by the $1 \%$ of taxpayers having the highest income account for more than $35 \%$ of all deductions. The deductions for charitable donations carried out by the top $25 \%$ income classes (middle-high, high and very-high) account for more than $70 \%$ of all such deductions in the taxpayer population. This information is important for the policymaking, as it suggests that calibrating tax incentives for this particular class of taxpayers could potentially be a policy option to consider.

In those descriptive statistics, there is no obvious correlation with the timing of the reform. The increase of deducters, as well as the decrease in the median of individual amounts deducted, are mostly constant and linear, with no distinctive or drastic changes in 2006 , when the new federal tax law norms took effect, nor in 2010, when cantonal adjustments were made. The increase in the overall amount of donations is not linear but subject to certain peaks, the largest of them (48\%) being observed in 2009, several years after the reform. We can speculate about the reasons thereof, for instance, the fact that in 2009, taxpayers who were usually taxed at source were given the possibility, under certain conditions, to file a return and then be treated 
as resident taxpayers (so-called "quasi-residents"), thus claiming all personalized deductions, including for charitable giving. ${ }^{32}$ It can be estimated that the number of such taxpayers was around 2,000 in 2009, 4,000 in 2010 and 5,600 in 2011. ${ }^{33}$ This fact could influence both the amount of deductions and the number of deducters. However, the data transmitted by the Geneva Tax Administration for the purpose of this study are confidential, not allowing identification of the quasi-residents and thus verification of whether and to what extent their deductions explain this peak in giving.

Overall, three important observations should be highlighted: first, over the 11 years under review, it appears that an increased number of taxpayers deducted their donations; second, the amount of those deductions decreased in terms of both mean and median; third, an overwhelming part of deductions came from the upper 25\% income class. With respect to the first two observations, the presented descriptive statistics do not show any conclusive evidence of the impact of the reform on those trends. As one of the goals of the 2006 reform was to encourage taxpayers to part with a substantial amount of their wealth, because the pre-reform level of giving was considered insufficient, the constantly decreasing median deduction could be a sign for legislators indicating that potentially the reform was unsuccessful on this point, at least for the lower 75\% classes of income. Yet, this would call for further investigations about the 2006 reform effects, because while the total amount of deductions is known, the total amount of donations is not. In relation to another implicit goal of the reforms - to attract new deducters - it is not possible to detect any evidence of the reform's real impact, because the number of deducting taxpayers has steadily increased since 2001, with no visible increase during the year of the reform or the years immediately following the entry into force of the new law provisions. This finding in any event may indicate a constantly increasing awareness of the population of tax deductions for charitable giving, perhaps independently of any specific tax reform incentive. Overall, there is evidence which seems to show that that the reform might not have succeeded in attaining at least some of its goals. This impression is strengthened by the fact that the 2006 reform substantially increased the possibilities for tax deductions, because it not only allowed larger deductions but also offered a possibility to deduct non-cash donations (including real estate) as well as donations to various public entities. Therefore, one would expect to see at least some effects of those important changes in the descriptive data, which is not the case in the present study.

Overall, more research ought to be done to understand whether the 2006 reform had any effect on charitable giving behavior and, if so, to what extent. Ideally, every new tax measure that has been introduced - the increase of the deduction threshold and the introduction of the deductibility of non-cash donations, as well as the possibility to deduct gifts to public entities - should be evaluated separately, trying to disentangle their effects. Moreover, a more specific study stratified by income could reveal additional insights. For instance, alternative data sets should be used to enable researchers to understand the changes in the total amounts of donations (and not only of deductions) during this period. Furthermore, studying the patterns of charitable giving to higher education institutions could help establish whether the tax reform increased - as intended - their funding from charitable sources. Finally, studying charitable non-cash donations would contribute to determining to what extent such a policy measure was successful. In order to complete those studies, allowing an in-depth evaluation of the new tax measures, legislators and the administration should make tax measure-segregated data (for instance, indicating the total amount of charitable donations for different income categories indicated previously) available for scientific studies. 


\section{Conclusion}

The present chapter provides unique descriptive statistics about taxpayer's giving behavior in the Canton of Geneva for the period from 2001 to 2011. Several important observations emerge. First, the number of taxpayers deducting charitable donations significantly increased. Second, in general, the median of individual amounts of charitable deductions decreased between 2001 and 2011 (even without inflation adjustment), and this effect is observed in all income classes comparing the years 2001 and 2011. This could suggest that even though the total number of deducters increased, they tended to make individually smaller donations; however, an alternative data set would need to be studied in order to confirm this hypothesis (in particular having access to the total amount of donations and not only to the deducted amounts). Third, the taxpayers with the highest income, especially the very high income class (top 1\% of all the taxpayers) accounted for the largest percentage of deductions. Policy makers could consider whether tax incentives should target this specific group of taxpayers and whether to envisage other incentives which could be more attractive to a broader base of deducters (as proposed by other researchers).$^{34}$ Further interdisciplinary works studying the giving behavior of taxpayers belonging to the highest income classes could also usefully build on the present results in order to understand the rationale and what, in addition to tax incentives, moves taxpayers to make charitable donations. ${ }^{35}$

\section{Notes}

1 For examples of other jurisdictions, see OECD 2020, pp. 80-84.

2 Arts $33 \mathrm{a}$ and 56 let. $\mathrm{g}$ of the Direct Federal Taxation Act (DFTA).

3 For a more detailed description of the Swiss system, see Lideikyte Huber (2018).

4 Art. 9(1)(i) Direct Taxation Harmonization Act of 14 December 1990 (DTHA).

5 Code civil suisse (Droit des fondations), Modification du 8 octobre 2004, RS 4545.

6 Report 2003, p. 7426.

7 Schiesser initiative; Report 2003, pp. 7426-7427.

8 Report 2003, p. 7428.

9 Schiesser Initiative.

10 The reform also introduced changes in the Value Added Tax and Withholding Tax Acts, but they will not be considered in the framework of the present chapter.

11 FR: Commission de l'économie et des redevances.

12 Report 2003, p. 7431.

13 Draft Federal Act, p. 7458 et seq.

14 The consultation procedure is the phase of the preliminary legislative procedure during which federal projects of great political, financial, economic, ecological, social or cultural significance are examined as to whether they are materially correct, feasible and likely to be well accepted. https://www.fedlex. admin.ch/fr/consultation-procedures/explanations-cp access date 15.09.2021. Consultation procedures are defined by the Federal Act on the Consultation Procedure of 18 March 2005 (Consultation Procedure Act, CPA).

15 Federal Council, p. 7467.

16 Federal Council, p. 7467.

17 Federal Council, pp. 7466-7467.

18 Federal Council, p. 7467.

19 Federal Act Modifying CC, p. 4551.

20 In its message, this recognizes the need for rules to establish uniform practice and considers it advisable to provide for an ordinance to this effect. Federal Council, p. 7466.

21 Federal Parliament, deliberation 00.461 Pa. Iv. Schiesser Fritz. Revision of the Law on Foundations Report 2003, p. 7426.

22 Schiesser initiative; also see parliamentary deliberations on Schiesser initiative No. 00.461, p. 1216. 
23 Report 2003, p. 7432.

24 Personal Income Tax Act - V (FR: Loi sur l'imposition des personnes physiques (LIPP-V) Détermination du revenu net - Calcul de l'impôt et rabais d'impôt - Compensation des effets de la progression à froid du 22 septembre 2000, D 3 16; in force: 01.01.2001).

25 Personal Income Tax Act of September 27, 2009 (FR: Loi sur l'imposition des personnes physiques du 27 septembre 2009; LIPP; D 3 08, in force: 01.01.2010).

26 Corporate Income Tax Act of September 23, 1994 (FR: Loi sur l'imposition des personnes morales du 23 septembre 1994, D 3 15; in force: 01.01.1995).

27 The authors of this chapter have contacted the Swiss Federal Office of Statistics, Swiss Federal Tax Administration, Swiss Federal Department of Finance and Swiss Federal Audit Office for these purposes. All the sources confirmed that no evaluations were carried out about the efficiency of this tax reform.

28 Federal Bureau of Statistics, regional comparison according to selected criteria, 2020, https://www. $\mathrm{bfs}$.admin.ch/bfs/fr/home/statistiques/statistique-regions/portraits-regionaux-chiffres-cles/cantons. assetdetail.11587764.html access date 04.03.2021.

29 On this topic, also see Chapter 12 of this Handbook, Adena Maja, Tax-price elasticity of charitable donations - evidence from the German taxpayer panel.

30 See Adena et al., 2014.

31 See Adena et al., 2019.

32 Personal Income Tax Bill of the Canton of Geneva of 16.01.2008, PL 10199 https://www.google. $\mathrm{com} / \mathrm{url}$ s $\mathrm{sa}=\mathrm{t} \& \mathrm{rct}=\mathrm{j} \& \mathrm{q}=\& \mathrm{esrc}=\mathrm{s} \&$ source $=$ web $\& \mathrm{~cd}=\& \mathrm{ved}=2 \mathrm{ahUKEwiB} 6 \mathrm{MClrqHwAhXGsKQK}$ HZ3CCIwQFjABegQIBhAD\&url=https\%3A\%2F\%2Fge.ch\%2Fgrandconseil\%2Fdata\%2Ftexte\%2 FPL10199.pdf\&usg=AOvVaw0HcXiLL1mRvpRmQH8HNvVz access date 28.04.2021; Art. 31 Art. 12 par. 1 of the Regulations for the implementation of the law on withholding tax on natural and legal persons of the Canton of Geneva [FR: Reglement d'application de la loi sur l'imposition a la source des personnes physiques et morales (RISP) du 30 September 2020; rsGE D 320.01$]$.

33 Information provided by the Canton of Geneva together with the data for the present study.

34 See Chapter 15 of this Handbook, Nicolas J. Duquette/Jennifer Mayo, Who gives and who gets? Tax policy and the long-run distribution of philanthropy in the US.

35 For further developments on this topic, see the chapters of this handbook by Andreoni/Smith, Duquette/ Mayo, Bernardic et al. A study in progress by Lideikyte Huber and Pittavino, to be published in 2022, pursues the analysis of the Canton of Geneva further using a new set of tax data.

\section{Bibliography}

Adena, M. Huck, S. Giving once, giving twice: A two-period field experiment on intertemporal crowding in charitable giving, Journal of Public Economics 172, 127-134 2019. https://www.sciencedirect.com/ science/article/pii/S0047272719300027

Adena, M. Alizade, J. Bohner, F. Harke, J. Mesters, F. Quality certification for nonprofits, charitable giving, and donor's trust: Experimental evidence, Journal of Economic Behavior \& Organization 159, 75-100 2019

Adena, M. Huck, S. Rasul, I. Charitable giving and nonbinding contribution-level suggestions. Evidence from a field experiment, Review of Behavioral Economics 1 2014. https://papers.ssrn.com/sol3/papers. cfm?abstract_id $=2407898$

Draft Federal Act modifying the Civil Code, the Direct Federal Taxation Act, the Withholding Tax Act and the Federal Act on Value Added Tax (Draft Federal Act), FF 20037453 ("Draft Federal Act")

Federal Act of October 8, 2004 modifying the Civil Code, the Direct Federal Taxation Act, the Withholding Tax Act and the Federal Act on Value Added Tax, RO 20054545 ("Federal Act Modifying CC")

Freitag, M. Paul C. B. Was uns zusammenhält: Zwischenmenschliches Vertrauen als soziales Kapital in der Schweiz. In: Markus Freitag (dir.): Das soziale Kapital der Schweiz. Zurich: Verlag Neue Zürcher Zeitung, pp. 149-179 2016

Lideikyte Huber, G. Philanthropy and taxation: Swiss legal framework and reform perspectives. Expert Focus 3 20-24 2018

OECD. Taxation and Philanthropy, OECD Tax Policy Studies, No. 27, 2020. Paris: OECD Publishing. https://doi.org/10.1787/df434a77-en (access date 2 March 2021)

Opinion of the Federal Council of December 5, 2003 on the Parliamentary initiative "Revision of the Law on Foundations (Schiesser)" and on the Report of the Committee for Economic Affairs and Taxation of the Council of States of 23 October 2003 (FR: Avis du Conseil federal - Initiative parlementaire Révision 


\section{Tax incentives for charitable giving}

du droit des fondations (Schiesser), Rapport de la Commission de l'économie et des redevances du Conseil des Etats du 23 octobre 2003)

Parliamentary Initiative No. 00.461 "Revision of the Law on Foundations of 14.12.2000" ("Schiesser initiative") (FR: Initiative parlementaire No. "Révision de la législation régissant les fondations"). https:// www.parlament.ch/fr/ratsbetrieb/suche-curia-vista/geschaeft?AffairId=20000461 (access date 10 March 2021)

Report of the Economic Affairs and Taxation Committee on the Parliamentary initiative "Reform of the legislation governing foundations" of October 23, 2003), RS 00.461, ("Report 2003")(FR: Rapport de la Commission de l'économie et des redevances du Conseil des Etats du 23 octobre 2003 Initiative parlementaire "Révision de la législation régissant les fondations")

State Secretariat for Education, Research and Innovation, "Higher education and research in Switzerland" (FR: Secrétariat d'Etat à la formation, à la recherche et à l'innovation, "L'enseignement supérieur et la recherche en Suisse”). www.sbfi.admin.ch/campus-switzerland-f.html (access date 8 March 2021) 


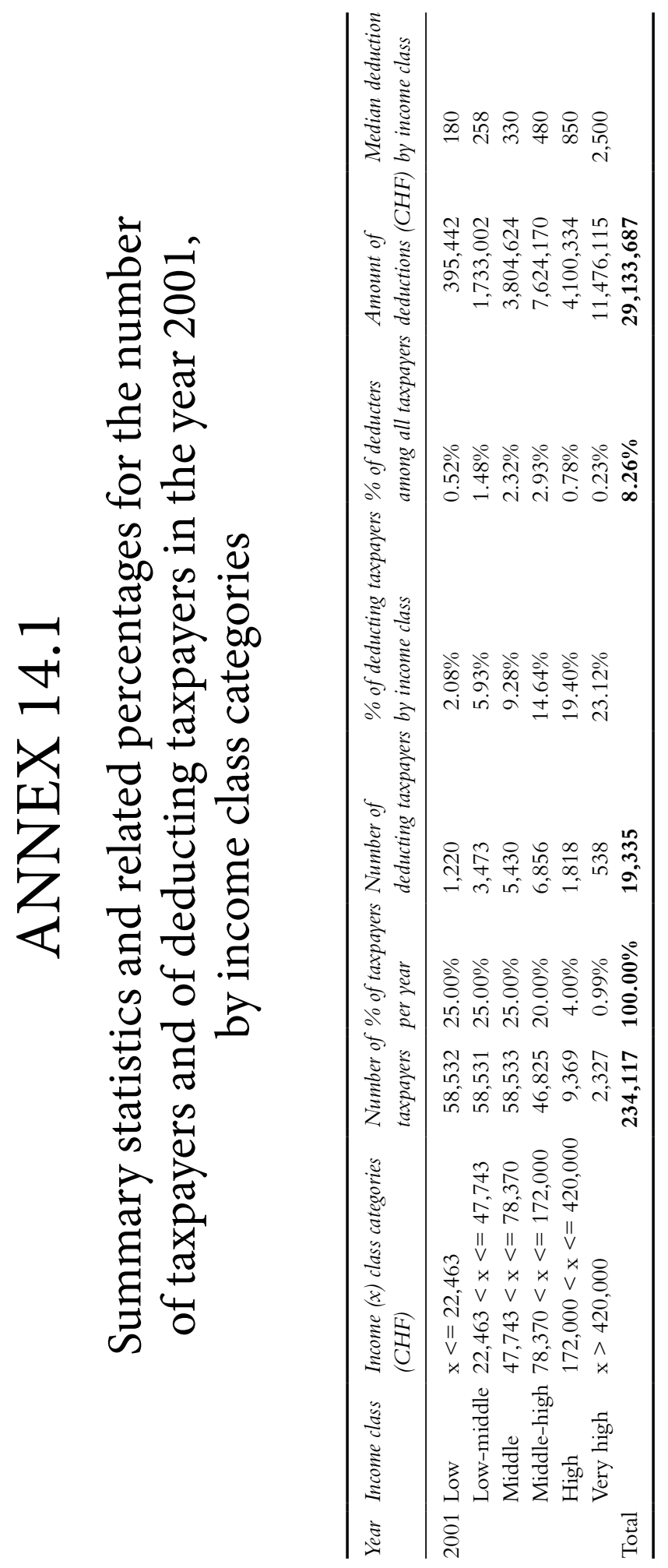




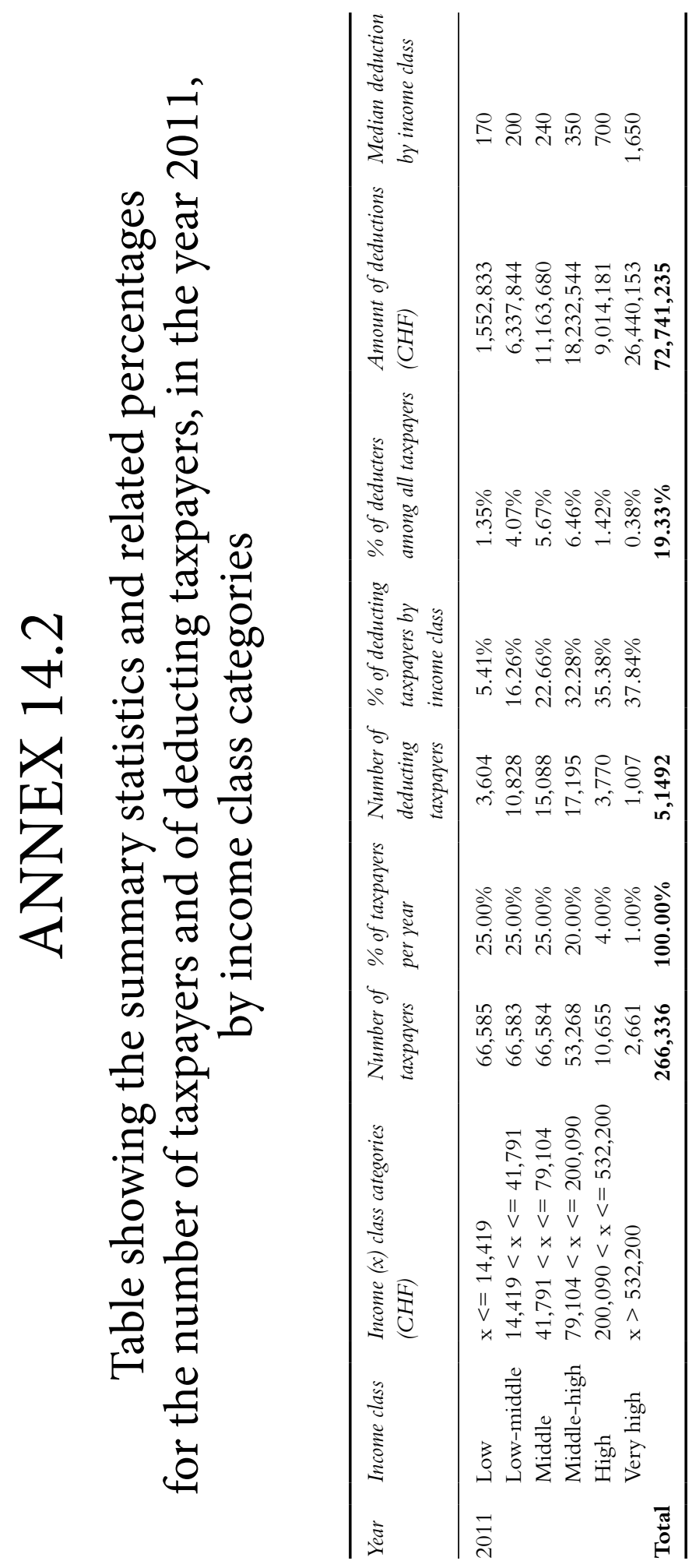

